\title{
Cold tolerance of selective breeding of Oreochromis niloticus and oreochromis aureus
}

\author{
Mahmoud A. Rezk and Ebtehag A. Kamel
}

Genetics and Breeding Department, Central Laboratory for Aquaculture Research, Abbassa, Egypt. Agricultural Research center.

Corresponding author: E-mail address: ebtehagkamel@yahoo.com

\begin{abstract}
Selected fish for higher growth rate from both $O$. niloticus and $O$. aureus were collected and subjected to challenge test for cold. In addition to, fish of both species collected from production ponds of Abbassa were used to compare the cold tolerance of fish. Fry of similar age were grown under identical conditions. O. niloticus with an average weight of $1.29 \pm 0.73 \mathrm{~g}$ and $0.95 \pm 0.11 \mathrm{~g}$, for $O$. aureus were used in this study. The selected $O$. niloticus revealed lower cold tolerance than the non-selected fish. The cooling degree hours were significantly different between the selected and non-selected $O$. niloticus $(\mathrm{P}<0.005)$. The selected $O$. aureus exhibited greater cold tolerance than the non-selected and death began at $14.1^{\circ} \mathrm{C}$, while nonselected occurred at $15.2^{\circ} \mathrm{C}$.

The lowest lethal temperature of $50 \%$ individuals was $8.7^{\circ} \mathrm{C}$ for selected $O$. aureus at 198 cooling degree hours $(\mathrm{CDH})$ and $9.3^{\circ} \mathrm{C}$ for non-selected fish at $147 \mathrm{CDH}$. Both selected and non-selected fish gave lowest lethal temperature of $60 \%$ individuals at $8.5^{\circ} \mathrm{C}$. But in different degree hours which was longer in selected $(220 \mathrm{CDH})$ and shorter in non-selected (182CDH) .The selected fish with stood 330 cooling hours which was higher than that for the non-selected fish (311 CDH).
\end{abstract}

There was strong relationship between the cold and both temperature at death and cumulative degree hours represented by negative correlation coefficient for all tested fish $(-0.928 \pm 0.014)$. There was no correlation between cold tolerance and fish size for all tested fish.

\section{INTRODUCTION}

In aquaculture industry in tropical and subtropical regions of the world, tilapia plays an important role in fish production. The ability of tilapia to tolerate wide ranges of water quality, diets and farming system help in transferring and distributing tilapia from Africa to many countries.

Tilapia is not able to grow and survive in cold waters outside its environment; before it is adapted (Gjedrem, 2005). Since different tilapia species and strains have been introduced to many different geographical regions of the world, their response to water temperature in their new habitats requires prime attention (El-Sayed, 2006). Egyptian tilapia is the best populations in growth during genetic improved tilapia (GIFT) program in Asia (Eknath et al., 1993). 
Tilapia generally survived constant at minimum temperatures over $12{ }^{\circ} \mathrm{C}$ but survival rate was mediated by the rate of decline, mass-length ratio and strain. For every $1{ }^{\circ} \mathrm{C}$ increase in minimum temperature, tilapia was 2.76 times more likely to survive. Fish exposed to rapid temperature decline were less likely to survive than those exposed to slowly decreasing temperature (Wilson et al., 2009). The survival rates of Oreochromis aureus juveniles, in concrete ponds and hapas suspended in earthen ponds, during the hard winter conditions in Egypt were recorded by Kamel et al. (2008).

Cold tolerance is a trait of great economic importance in tilapia, as severe mortalities occur during the winter in temperate climate countries (Tave et al., 1990). The variation of cold tolerance among and within species is correlated to their geographical distribution (Khater \& Smitherman, 1988). Also, the inability of tilapia to tolerate low temperature is of major economic concern as it reduces their growing season and leads to over winter mortality (Charo-Karisa et al., 2005).

It is well documented that during winter, water temperature may drop to levels that cause severe growth inhibition and mortality. The fluctuation by increasing and decreasing of temperature during autumn and spring, affect the fish reproductive physiology and fry production.

The tolerance of tilapia species and their hybrid to cold was recorded (El Gamal, 1988; Khater \& Smitherman, 1988; Behrends et al., 1990; Tave et al., 1990; Cnaani et al., 2000; Sifa et al., 2002).
Several studies have been carried out on interspecific hybrids of tilapia under ambient winter temperatures and concluded that cold tolerance behaved as a dominant trait (Wohlfarth et al., 1983). On the other hand, studies by Behrends et al. $(1990,1996)$ and Tave et al. (1990) with $O$. aureus and $O$. niloticus under ambient winter temperatures concluded that cold tolerance was inherited as an additive trait.

Selection breeding can enhance the cold tolerance of tilapia (Behrends \& Smitherman, 1984). The tolerance of selective GIFT tilapia to cold was reported (Sifa et al., 2002). Cold tolerance as a trait has been variously described. It has been described as low lethal temperature or temperature at death (TAD) (Khater and Smitherman, 1988; Behrends et al., 1990; Atwood et $a l ., 2003)$. It has also been described as cooling degree days (CDD) or cumulative degree hours (CDH) (Behrends et al., 1990; Cnaani et al., 2000; Atwood et al., 2003) or simply as by number of days until death (Tave et al., 1989).

The aim of this investigation was to study the impact of selection for higher body weight on improving cold tolerance in $O$. niloticus and $O$. aureus.

\section{MATERIALS AND METHODS}

\section{Stock fish:}

The original stock of Oreochromis niloticus fry fish used in this study was from Maruit hatchery and adapted to Abbassa environmental condition at 1999 (Kamel, 1999), while Oreochromis aureus from the production ponds at Abbassa was studied by Rezk et al. (2002). Fry of the same age from the fifth generation 
of mass selection, of $O$. niloticus and O.aureus from the World Fish Center, Abbassa, Egypt were used, in addition to unselected fish groups for both, used as control groups. All groups for selected and unselected fry of similar age and grown under identical conditions $O$. niloticus were with an average weight of $1.29 \pm 0.73 \mathrm{~g}$, while, it was $0.95 \pm 0.11 \mathrm{~g}$, for O.aureus. The fry was transferred from hapas suspended in earthen ponds to glass aquaria (450 1). Two replicates aquaria for each group, random sample of one hundred fry per aquarium in addition to, one aquarium with water only. All fry were acclimated for one week to aquaria condition before starting the experiment and the aeration in the aquaria by air stone from air pump.

\section{Challenge test for cold}

Nine aquaria were placed in cold room operated by a thermostatically controlled chilling unit. The fry were acclimated at ambient temperature (20 $\left.{ }^{\circ} \mathrm{C}\right)$. Each aquarium was constantly aerated using three air-stones connected to an air-pump.

The temperature of the aquarium water was adjusted to the desired level by adjusting the thermostat controlled chilling unit.

The acclimatizing the fry was done at $20{ }^{\circ} \mathrm{C}$ for 48 hours. After that aquarium water temperature was monitored each hour from the beginning to the end of the experiment.

The temperature measurements were done hourly, while the dissolved oxygen (DO), $\mathrm{pH}$, total ammonia, nitrate and nitrite were measured once a day, using a WTWR multi 340i meter and $\mathrm{HACH}$ kits. Dissolved oxygen ranged between 6.1 and 10.3 $\mathrm{mg} / \mathrm{l} ; \mathrm{pH}, 7.9-8.3$; ammonia, 0.01-0.1 $\mathrm{mg} / \mathrm{l}$; nitrate, $0.5-2 \mathrm{mg} / \mathrm{l}$; and nitrite,
0.01-0.02 mg/l. Aquaria were cleaned twice daily by suction to remove faeces. Water that was removed during aquarium cleaning was replaced with clean water pre-cooled to the same temperature with ice cubes.

Fish were not fed during the experiment. Temperature was first lowered to $16{ }^{\circ} \mathrm{C}$ within $48 \mathrm{~h}$, and then water temperature was reduced at a rate of $1{ }^{\circ} \mathrm{C}$ daily till the end of the experiment. Aquaria were observed once each hour for any fish mortality. Death was defined as the point at which fish lost balance, fell on their side and ceased fin, body and opercula movements and lost response to external stimuli. Throughout the experiment, dead fish were removed from the tanks at the end of each hour with a scoop net, and their tag and aquarium numbers recorded. Mortality was recorded hourly for each fish, which enabled us to quantify cooling degree hours $(\mathrm{CDH})$ Temperature at death (TAD), recorded hourly, was used in this study to measure the cold tolerance.

\section{Data Analysis}

The mean cooling-degree hours regression and correlation were calculated by SAS program. Individual cold tolerance was quantified using a cooling-degree-hours (CDH) statistic (after Cnaani et al., 2000), calculated as

$$
\mathrm{CDH}=\sum_{i=1}^{k}\left(t_{o}-t_{i}\right)
$$

Where: $i=$ days, $t_{o}=16 \_\mathrm{C}$, the initial temperature, $t_{i}=$ temperature at the temperature measured at check-point $i$, and $\mathrm{k}$ is the check-point when mortality of the fish was recorded. For example, the score for a fish that survived 1 hour in $15.5{ }^{\circ} \mathrm{C}$ and I hour 
in $15^{\circ} \mathrm{C}$, is $(16-15.5)+(16-15)=1.5$ hour.

\section{RESULTS}

The cold tolerance among the tested fish varied as shown in Table (1). The mortality was started for selected $O$. niloticus at $14.8{ }^{\circ} \mathrm{C}$, while the non-selected fish began to die at $13.6^{\circ} \mathrm{C}$.

The lowest lethal temperature of $50 \%$ individuals was $9.9{ }^{\circ} \mathrm{C}$ for selected $O$. niloticus fish and complete mortality occurred at $8.5{ }^{\circ} \mathrm{C}$. At the same time the lowest lethal temperature of $50 \%$ individuals was $8.9^{\circ} \mathrm{C}$ for non-selected fish (Table 1). The cooling degree hours were significantly different between the selected and non-selected $O$. niloticus $(\mathrm{P}<0.005)$. The selected fish survived up to 260 cooling hours, which was lower than that for the non-selected fish (294 CDH) as recorded in Table (1).

The selected $O$. aureus exhibited greater cold tolerance than the nonselected and started to die at $14.1{ }^{\circ} \mathrm{C}$, against unselected death at $15.2{ }^{\circ} \mathrm{C}$ (Figure 1A,B). The lowest lethal temperature of $50 \%$ individuals was $8.7^{\circ} \mathrm{C}$ for selected $O$. aureus and 9.3 ${ }^{\circ} \mathrm{C}$ for non-selected fish. The cooling degree hours of $50 \%$ individuals was $198 \mathrm{hrs}$ for selected O.aureus and 147 hrs for non-selected fish (Table 2).

Both selected and non-selected fish gave lowest lethal temperature of $60 \%$ individuals at $8.5^{\circ} \mathrm{C}$. But in different cooling degree hours which was longer in selected $(220 \mathrm{CDH})$ and shorter in non-selected (182CDH). From lowest lethal temperature of 70 individuals, the non-selected exhibited more tolerance to cold. Complete mortality occurred at $7.8^{\circ} \mathrm{C}$ for selected and 7.4 ${ }^{\circ} \mathrm{C}$ for non-selected fish.
The selected fish survived up to 330 cooling hours which was higher than that for the non-selected fish (311 $\mathrm{CDH}$ ) as recorded in Table (1)

There was no correlation between cold tolerance and fish size for all tested fish.

\section{DISCUSSION}

The results of the experiment indicated that the selected fish of $O$. niloticus (Abbassa) was less tolerate to cold which agreed with Sifa et al. (2002) they recorded higher tolerance to cold for Egypt 88 than the genetic improved farmed tilapia (GIFT). But during study of the growth of Abbassa fish was the lowest as recorded by (Kamel, 1999), this means that there was no correlation between growth and cold tolerance.

The selected fish was introduced to Abbassa at 1995 as fingerlings from Maryout hatchery and gave the highest growth rate as recorded By Kamel (1999) and Rezk et al. (2002); newly introduced tilapia have lower cold tolerance than those which have been introduced and adapted to local cold temperature for a longer time (ElSayed, 2006). They had not previously been exposed to the selective pressures of low temperature, while, fish from Abbassa station were introduced from Ismailia Canal and had acclimatized during the winter condition in ponds to tolerate the decreasing temperature; which agreed with Cnaani and Hulata (2000) who reported that better fish survival rate during winter due to longer period of time as the fish were exposed to low temperatures on the farms. Temperature at death incidences detected in this study were in full agreement with those reported in earlier studies on $O$. niloticus. Many records for the mortality of the 
Egyptian strain has been reported at 11 ${ }^{\circ} \mathrm{C}$ to $9{ }^{\circ} \mathrm{C}$ (Khater and Smitherman, 1988), $13{ }^{\circ} \mathrm{C}$ to $10{ }^{\circ} \mathrm{C}$ (Lahav and Ra'anan, 1998) and $10.1^{\circ} \mathrm{C}$ to $8.6^{\circ} \mathrm{C}$ (Charo-Karisa et al., 2005). Better cold tolerance was recorded with the first mortality at $11{ }^{\circ} \mathrm{C}$ and total mortality at $7.4{ }^{\circ} \mathrm{C}$ for the Egyptian strain of $O$. niloticus used in China with fish size ranged from 60-120 g, (Sifa et al., 2002). El Gamal, 1988 mentioned lower lethal temperature (LC50) for $T$. nilotica $\left(8.28^{\circ} \mathrm{C}\right)$ and $T$. aurea $\left(7.33{ }^{\circ} \mathrm{C}\right)$. The differences among all earlier experiments for cold and this study were due to the difference in fish size which was 1.29 $\pm 0.73 \mathrm{~g}$ in this study. The same observation was recorded by Hofer and Watts (2002), who illustrated that smaller fingerlings, below5 $\mathrm{g}$, were more susceptible to acute exposure to lower temperatures stress. No correlation was recorded for fish weight and cold tolerance for all tested fish which agreed with Cnaani et al. (2000). Also body weight within populations was not significant factors affecting cold tolerance (Behrends, 1990). Size significantly affected mortality, with smaller fish being less tolerant to low temperatures than larger fish (Atwood et al., 2003). In contrast, strong impact of weight on cold tolerance was reported by (CharoKarisa et al., 2005). There was strong relationship between the cold and both temperature at death and cumulative degree hours as indicated by negative correlation coefficient for all tested fish $(-0.928 \pm 0.014)$. The same observation was recorded with $O$. niloticus by Charo-Karisa et al. (2005), who recorded negative correlation ($0.88 \pm 0.019)$. The lowest lethal temperature of $50 \%$ individuals was
$8.7{ }^{\circ} \mathrm{C}(198 \mathrm{CDH})$ for selected $O$. aureus and $9.3{ }^{\circ} \mathrm{C}(147 \mathrm{CDH})$ for nonselected fish. Both selected and nonselected fish gave the lowest lethal temperature of $60 \%$ individuals at 8.5 ${ }^{\circ} \mathrm{C}$; but in different cooling degree hours which was longer in selected $(220 \mathrm{CDH})$ and shorter in non-selected (182CDH). The pervious results indicated that the cooling degree hours was more accurate measure of the genetic variation in cold tolerance than the temperature at death which agreed with Charo-Karisa et al. (2005). The results indicated positive genetic correlation response to selection for higher growth rate and cold tolerance in O. aureus, while it was negative for $O$. niloticus which agreed with Dunham (2006) who concluded that correlated responses to selection affected several other traits, both positively and negatively. Gjedrem and Baranski (2009) reported that selection for one trait will influence other traits that are genetically correlated and Fjalestad (2005) who found that farmed Atlantic salmon fish from seven generations of selection for increased growth rate seems to be less sensitive to environmental stress than genetically wild fish.

\section{CONCLUSION}

The selected $O$. niloticus fish was less tolerate to cold which mean that the selection for higher growth rate had negative effect to cold. While the selected $O$. aureus showed that tolerance to cold was positively correlated with selection. The cooling degree hours were more accurate measure of the genetic variation in cold tolerance than the temperature at death. No correlation was recorded for fish weight and cold tolerance for all tested fish 


\section{REFERENCES}

Agresti J.J., Seki S., Cnaani A., Poompuang S., Hallerman E.M., Umiel N., Hulata G., Gall G.A.E. and May B. (2000): Breeding new strains of tilapia: development of an artificial center of origin and linkage map based on AFLP and microsatellite loci. Aquaculture, 185, 43-56.

Atwood, H.L., Tomasso, J.R., Webb, K. and Gatlin, I. D.M.(2003): Low-temperature tolerance of Nile tilapia, Oreochromis niloticus effects of environmental and dietary factors. Aquaculture, 34, 241-251.

Behrends, L.L., Kingsley, J.B. and Bulls, M.J.(1996): Cold tolerance in maternal mouthbrooding tilapias: heritability estimates and correlated growth responses at suboptimal temperatures. In: Pullin, R.S.V., Lazard, J.M., Legendre, J.B, Kothias, A., Pauly, D. (Eds.), The Third International Symposium on Tilapia in Aquaculture, ICLARM Conference Proceedings, vol. 41, pp. 257-265.

Behrends L.L., Kingsley J.B. and Bulls, M. J. (1990): Cold tolerance in maternal mouth brooding tilapias: phenotypic variation among species and hybrids. Aquaculture, 85, 271-280

Behrends, L.L. and Smitherman, R.O.(1984): Development of a cold-tolerant population of red tilapia through introgressive hybridization. Journal of the World Mariculture Society, 15, 172- 178 .
Society $15,172-178$.

Charo-Karisa, H., M. A. Rezk, H. Bovenhuis, and H. Komen. (2005): Heritability of cold tolerance in Nile tilapia, Oreochromis niloticus, juveniles. Aquaculture, 249, 115-123.

Cnaani, A., Gall, G.A.E. and Hulata, G.(2000): Cold tolerance of tilapia species and hybrids. Aquaculture International, 8, 289-298.

Dunham, R.A. (2006): Comparison of six generations of selection, interspecific hybridization, intraspecific crossbreeding and gene transfer for growth improvement in Ictalurus catfish. IAGA, 26-30 June, Montpellier, Abstract: 22.

Eknath, A.E., Tayamen, M.M., Palada-de Vera, M.S., Danting, J.C., Reyes, R.A., Dionisio, E.E., Capili, J.B., Bolivar, H.L., Abella, T.A., Circa, A.V., Bentsen, H.B., Gjerde, B., Gjedrem, T. and Pullin, R.S.V. (1993): Genetic improvement of farmed tilapias: the growth performance of eight strains of Oreochromis niloticus tested in different farm environments. Aquaculture, 111, 171-188.

El Gamal, A. R. (1988): Reproductive performance, sex ratios, gonadal development, cold tolerance, viability and growth of red and normally pigmented hybrids of Tilapia aurea and T. nilotica. $\mathrm{PhD}$ thesis, Auburn University, Auburn, Alabama

El-Sayed, A.-F. M. (2006): "Tilapia Culture". CABI Publishers, 
Wallingford, Oxfordshire, OX10 8DE, UK, 277 pp.

Gjedrem, T. (2005): Selection and breeding programs in aquaculture Genotype - environment interaction selection and breeding programs in aquaculture. edited by Trygve Gjedrem Springer Dordrecht, Berlin, Heidelberg, New York 364P.

Gjedrem, T . and Baranski, M. (2009): Selective Breeding in Aquaculture: An Introduction . Reviews: Methods and Technologies in Fish Biology and Fisheries. edited by Jennifer L. Nielsen Springer Dordrecht Heidelberg London New York 221P.

Fjalestad, K.T.(2005): Selection and breeding programs in aquaculture, Selection methods. edited by Trygve Gjedrem Springer Dordrecht, Berlin, Heidelberg, New York 364P.

Hofer, S.C. and Watts, S.A.( 2002): Cold tolerance in genetically male tilapia (GMTR), Oreochromis niloticus. World Aquaculture, 33, 19- 21.

Kamel. A, K. (1999): Genetic studies on Nile tilapia (Oreochromis niloticus) in Egypt Ph.D. Thesis Girls College for Arts, Science and Education. Ain Shams University, Egypt

Kamel, E. A., Elghobashy, H. A. and Farag, M. A. (2008): Performance of growth and survival rates of Oreochromis aureus juveniles during hard winter condition in Egypt. The Eighth International Symposium on Tilapia in
Aquaculture (ISTA VIII) 12-14 October 2008, Cairo International Convention Center (CICC). Egypt

Khater, A.A. and Smitherman, R.O. (1988): Cold tolerance and growth of three strains of Oreochromis niloticus. In: Pullin, R.S.V., Bukhaswan, T., Tonghthai, K., Maclean, J.L. (Eds.), The Second International Symposium on Tilapia in Aquaculture, ICLARM Conference Proceedings, vol. 15. ICLARM, Manila, Philippines, pp. 215-218

Lahav, E. and Ranan, Z.(1998): Cold tolerance of genetically produced all-male tilapia hybrids (Oreochromis aureus). In: Fitzimmons, K. (Ed.), Tilapia Aquaculture, Proceedings from the Fourth International Symposium on Tilapia Aquaculture Northeast Regional Agricultural Engineering Service (NRAES). Ithaca, NY, USA, pp. 662- 670 .

Rezk, M.A., Kamel, E.A., Ramadan, A.A. and Dunham, R.A.(2002): Comparative growth of Egyptian tilapias in response to declining water temperature. Aquaculture 207, 239-247.

Sifa, L., Chenhong, L., Dey, M., Gagalac, F. and Dunham, R. (2002):. Cold tolerance of three strains of Nile tilapia, Oreochromis niloticus, in China. Aquaculture 213, 123- 129.

Tave, D.(1990): Cold tolerance in tilapia. Aquaculture Magazine, 16 (4), 86-88.

Tave D., Jayaprakas V. and R. O. Smitherman. (1990): Effects of intraspecific hybridization in 
Tilapia nilotica on survival under ambient winter temperature in Alabama. Journal of the World Aquaculture Society, 21, 201-204.

Tave, D., Smitherman, R.O. and Jayaprakas, V.(1989): Estimates of additive genetic effects, maternal effects, specific combining ability, maternal heterosis, and egg cytoplasm effects for cold tolerance in Oreochromis niloticus (L). Aquatic Fishers and Management, 20, 159- 166.

Wilson, J. C., Nibbelink N. P. and Peterson D. L. (2009): Thermal tolerance experiments help establish survival probabilities for tilapia, a group of potentially invasive aquatic species. Freshwater Biology, 54 (8) 1642 1650

Wohlfarth, G.W., Hulata, G., Rothbard, S., Itzkowich, J. and Halevy, A. (1983) Comparisons between interspecific tilapia hybrids for some production traits. In: International Symposium on Tilapia in quaculture (eds. L. Fishelson and Z. Yaron), Tel Aviv University, Tel Aviv, Israel. pp. 559-569.

Table (1): Mortality percentage, cooling degree hours (CDH) and temperature at death (TAD) for selected and non-selected $O$. niloticus

\begin{tabular}{ccccc}
\hline & \multicolumn{2}{c}{$\begin{array}{c}\text { Selected } \\
\text { O. niloticus }\end{array}$} & \multicolumn{2}{c}{$\begin{array}{c}\text { Non-selected } \\
\text { Mortality \% }\end{array}$} \\
\cline { 2 - 5 } & CDH & TAD & CDH & TAD \\
\hline 10 & 12 & 14.8 & 29 & 11.3 \\
20 & 40 & 12.1 & 72 & 10.4 \\
30 & 63 & 11.0 & 114 & 9.8 \\
40 & 89 & 10.5 & 167 & 9.1 \\
50 & 119 & 9.9 & 195 & 8.9 \\
60 & 143 & 9.6 & 210 & 8.7 \\
70 & 150 & 9.5 & 225 & 8.5 \\
80 & 176 & 9.1 & 240 & 8.4 \\
90 & 210 & 9.3 & 270 & 8.3 \\
100 & 260 & 8.5 & 294 & 8.2 \\
\hline
\end{tabular}

Table (2): Mortality percentage, cooling degree hours (CDH) and temperature at death (TAD) for selected and non-selected $O$. aureus

\begin{tabular}{ccccc}
\hline \multirow{2}{*}{ Mortality \% } & \multicolumn{2}{c}{$\begin{array}{c}\text { Selected } \\
\text { O. aureus }\end{array}$} & \multicolumn{2}{c}{$\begin{array}{c}\text { Non-selected } \\
\text { O. aureus }\end{array}$} \\
\cline { 2 - 5 } & CDH & TAD & CDH & TAD \\
\hline 10 & 35 & 11.2 & 6 & 14 \\
20 & 73 & 10.2 & 20 & 12.7 \\
30 & 110 & 9.7 & 51 & 11.8 \\
40 & 157 & 9.2 & 98 & 10.4 \\
50 & 198 & 8.7 & 147 & 9.3 \\
60 & 220 & 8.5 & 182 & 8.5 \\
70 & 236 & 8.4 & 237 & 8.1 \\
80 & 259 & 8.3 & 245 & 8.1 \\
90 & 282 & 8.1 & 277 & 7.7 \\
100 & 330 & 7.8 & 311 & 7.4 \\
\hline
\end{tabular}



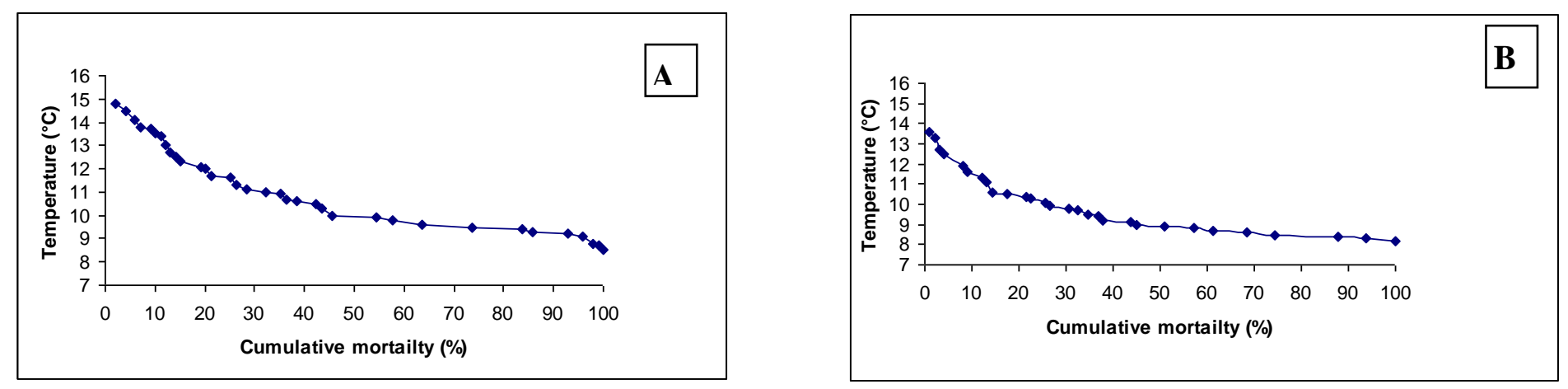

Figure (1). Cumulative mortality curves in cold-challenged for $O$. niloticus. (A) selected (B) non-selected
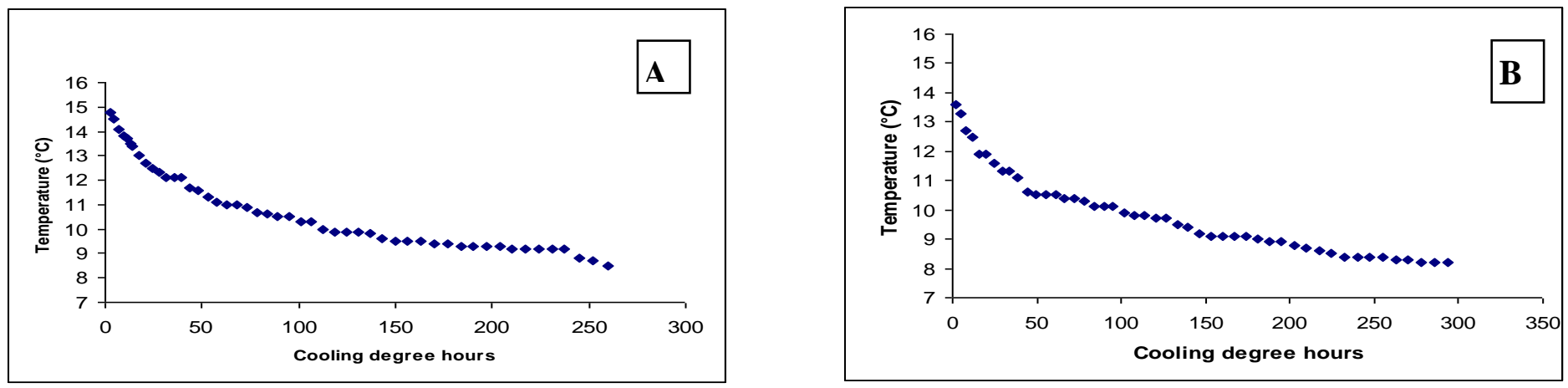

Figure (2). The relationship between the cooling degree hours and temperature for $O$. niloticus (A) selected (B) non-selected 

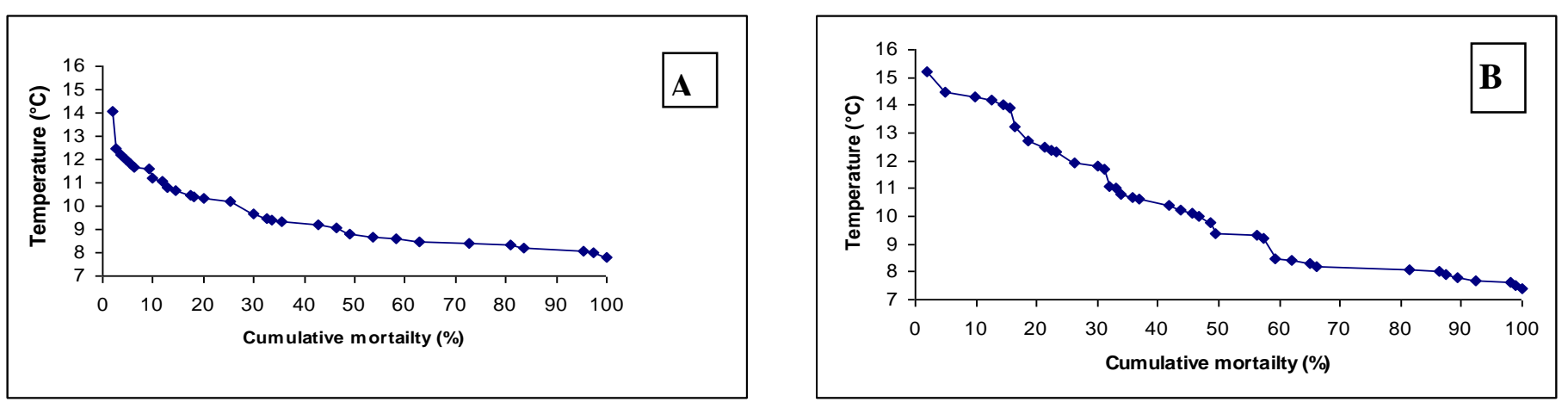

Figure (3). Cumulative mortality curves in cold-challenged for $O$. aureus (A) selected (B) non-selected
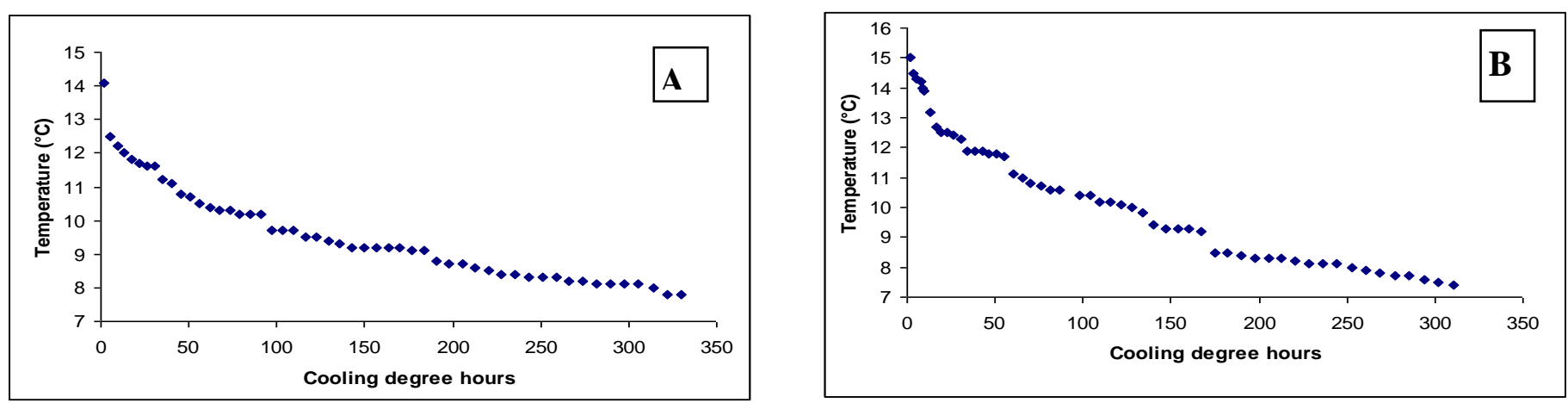

Figure (4). The relationship between the cooling degree hours and temperature for $O$. aureus (A) selected (B) non-selected 


\title{
تحمل البرودة لأسماك منتخبة وراثيا من البلطى النيلى و البلطى الاوريا
}

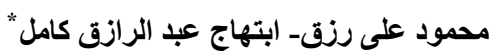 \\ قسم الور اثثة والتربية ـ المعمل المركزى لبحوث الثروة السمكية بالعباسة أبوحماد شرقيةـ مركز البحوث \\ الزراعية \\ ebtehagkamel@yahoo.com البريد الالكترونى:

$$
\text { الملخص العربى }
$$

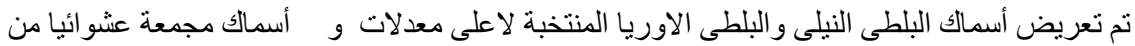

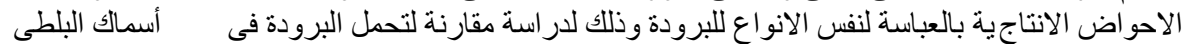
النيلى و البلطى الاوريا.

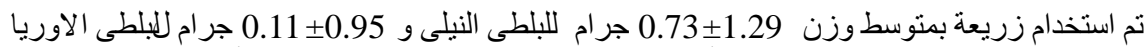

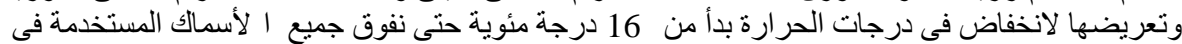

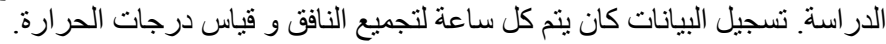
وقد اظهرت النتائج ان هناك فروق معنوية بين أسماك البلطى النيلى المنتخبة و غبر المنتخبة بيينما كانت أسماك البلطى النيلى المنتخبة أقل تحم لاً للبرودة عنوبة بن الأسماك غير البطى المنتخبة.

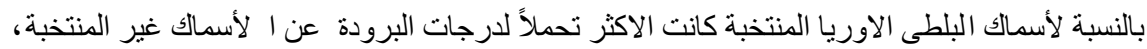

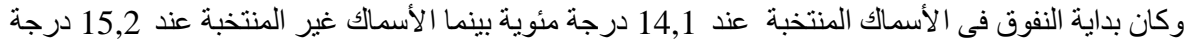

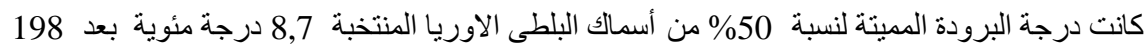
ساعة من التعرض لها. بينما كانت 9,3 درجة مئوية بعد 147 ساعة للأسماك غبر المبنة المنتخبة.

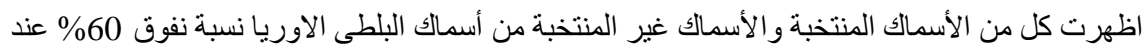

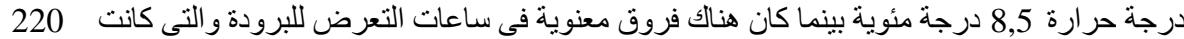

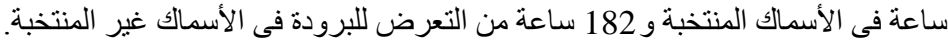

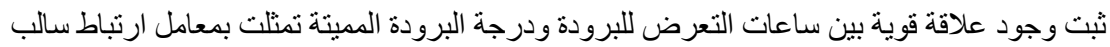

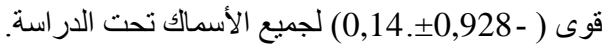

لم يتم تسجيل اى ارتباط بين تحمل البرودة وحجم الأسماك المستخدمة فى هذة التجربة

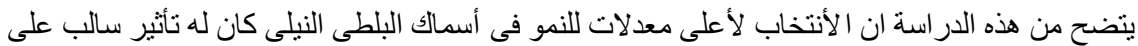

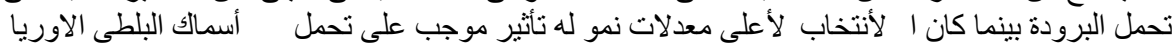
للبرودة. 